\title{
Relationship between Shear Wave Velocity and SPT-N Value for Residual Soils
}

\author{
Nor Faizah Bawadi ${ }^{1, *}$, Nur Jihan Syamimi Jafri ${ }^{1}$, Ahmad Faizal Mansor ${ }^{2}$, and Mohd Asri \\ Ab Rahim ${ }^{1}$ \\ ${ }^{1}$ School of Environmental Engineering, Universiti Malaysia Perlis, 02600 Arau, Perlis, Malaysia \\ ${ }^{2}$ Department of Civil Engineering Technology, Faculty of Engineering Technology, Universiti \\ Malaysia Perlis, 02100 Padang Besar, Perlis, Malaysia
}

\begin{abstract}
The shear wave velocity $\left(V_{s}\right)$ is an important dynamic parameter in the field of geotechnical engineering. One of the surface wave methods is Spectral Analysis of Surface Wave (SASW) has received attention in obtaining the shear wave velocity $\left(\mathrm{V}_{\mathrm{s}}\right)$ profile by analysing the dispersion curve. SASW is a non-destructive test, fast and time-effective for field survey. Thus, this paper proposed the application of SASW method to obtain the shear wave velocity $\left(\mathrm{V}_{\mathrm{s}}\right)$ to represent the soil profile. This paper aims to determine the shear wave velocity $\left(\mathrm{V}_{\mathrm{s}}\right)$ profile using SASW method, where the testing has been conducted at three site of residual soils located in Damansara, Kuala Lumpur and Nilai area. In this study, it shows that the soil profile obtained from shear wave velocity value is similar pattern with profile that obtained using Standard Penetration Testing (SPT), which conventional used in field. The shear wave velocity are proportionally increase with depth.
\end{abstract}

\section{Introduction}

The shear wave velocity $\left(\mathrm{V}_{\mathrm{s}}\right)$ is one of the important parameter in the field of geotechnical engineering. $V_{s}$ can be directly measured by in-situ seismic methods or laboratory tests. Insitu seismic methods can be invasive techniques such as suspension logging and cross-hole, down-hole test and non-invasive technique like seismic refraction method, spectral analysis of surface wave (SASW) method and multichannel analysis of surface wave (MASW) method. Invasive techniques require drilling into the ground. However, surface wave methods (e.g. SASW and MASW) has become the preferred method in geotechnical community for $\mathrm{V}_{\mathrm{s}}$ measurement because of their non-destructive and non-invasive approach to describe soil characteristics compare to other invasive seismic method which are costly and time-consuming.

Surface wave method have utilised Rayleigh wave for near surface applications, where it travels along the free surface of the earth with elliptical retrograde particle motion. The use of Rayleigh wave is considered for the dynamic properties of the subsurface are based on their dispersive nature, where the velocity propagation of Rayleigh wave is depend on

\footnotetext{
* Corresponding author: norfaizah@unimap.edu.my
} 
the frequency. Therefore, the higher frequency will penetrate deeper the shallow layer while the low frequency will penetrate deeper into the earth [1].

The first surface wave method called spectral analysis of surface waves (SASW) had introduced to produce near surface shear wave velocity profiles [2]. The main advantage of SASW test is the time consumption for field survey due to single pair receivers. Then, Kansas Geological Survey had developed an efficient and accurate method to estimate near surface shear wave velocity from ground-roll using multichannel seismic data from multichannel analysis of surface waves (MASW) test [3].

SASW is one of the most effective surface wave methods and widely used in evaluation of pavement systems [4] and site characterization [5].The SASW method is based on the relationship between Rayleigh wave phase velocities and depth-range of associated particle motion. In specific, the phase velocities of the component frequencies are calculated. The dispersion curve (phase velocity vs frequency) were then inverted to generate a shear wave velocity profile $[4,6,7]$. Thus, this paper presents the use of SASW method to obtain the shear wave velocity $\left(\mathrm{V}_{\mathrm{s}}\right)$ and investigate soil profile correspond with borehole data and shear wave velocity profile.

\section{Methodology}

\subsection{Sites location}

In this study, the SASW testing were carried out at three locations which are located at Damansara, Kuala Lumpur and Nilai area. All location was named as Site 1, Site 2 and Site 3. The field test configurations has been set up for each selected site. Fig. 1a and 1b shows a location of SASW testing at Site 1 and Site 2, where Fig. 1c shows three locations of SASW testing for Site 3. The results obtained from SASW were related to the SPT testing regarding to soil properties.

The shear wave velocity $\left(\mathrm{V}_{\mathrm{s}}\right)$ profiles obtained from the SASW testing for all three location sites were reviewed and compared with the others geotechnical data such as soil profile and SPT-N that obtained in soil investigation report, prepared by the contractor. Based on the previous researchers [8-9], the shear wave velocity value are directly proportionally increases to the depth of soil as SPT-N value. As refer to the previous results of this study, the correlation between SPT-N values and shear wave velocity can be reliable.
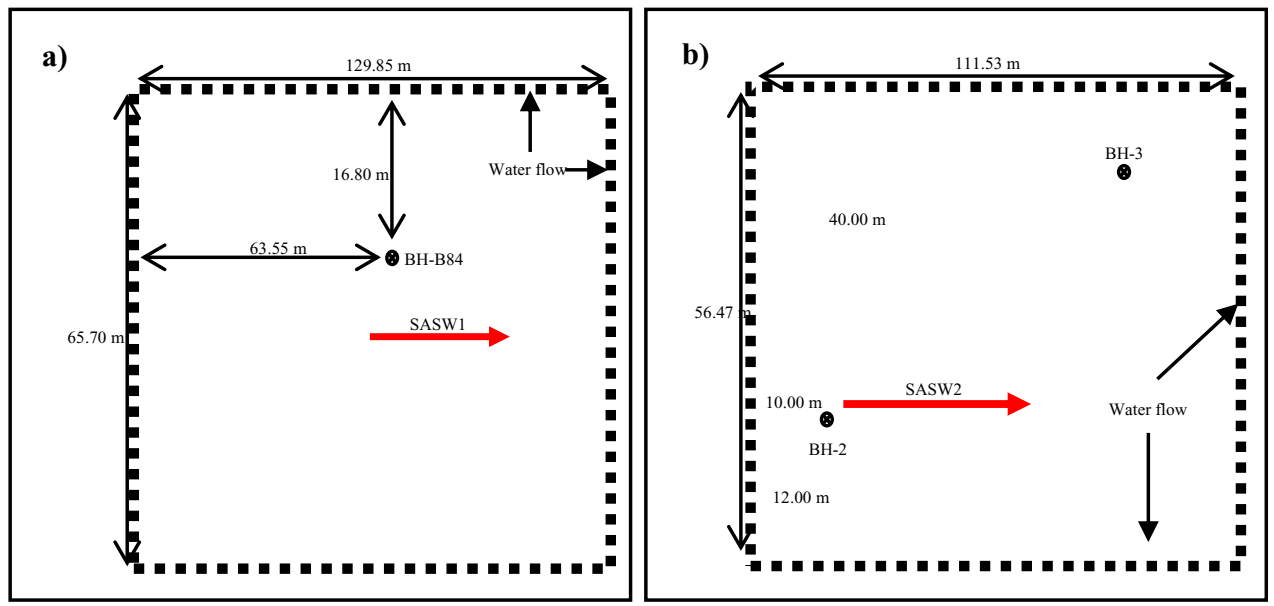


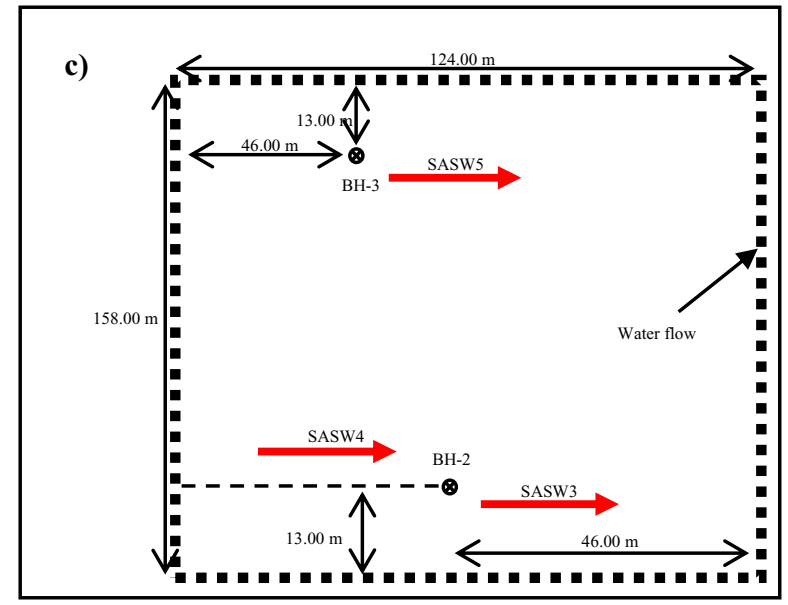

Fig. 1. A layout plan of SASW testing for a) Site 1, b) Site 2 and c) Site 3.

\subsection{SASW field testing}

In SASW method, Rayleigh waves are generated into ground by impacted source and detected by two receivers. All raw data are recorded by a spectrum analyser. For this study, the field measurements were conducted using a seismograph and two vertical geophones having a natural frequency of $1 \mathrm{~Hz}$ and geophone calibration factor is $400 \mathrm{~V} / \mathrm{m} / \mathrm{s}$. The source used is a transient source, which consists of different types of seismic impact in order to generate the vertical dynamic loads on the ground for a nearest-offset [10]. The sources used for nearest-offset were rubber hammer, geological hammer, steel hammer and iron hammer, while for far-offset was impact excavator machine. The configuration of field measurements was set up using Common Array Profiling (CAP), has shown in Fig. 2, as suggested by [11].

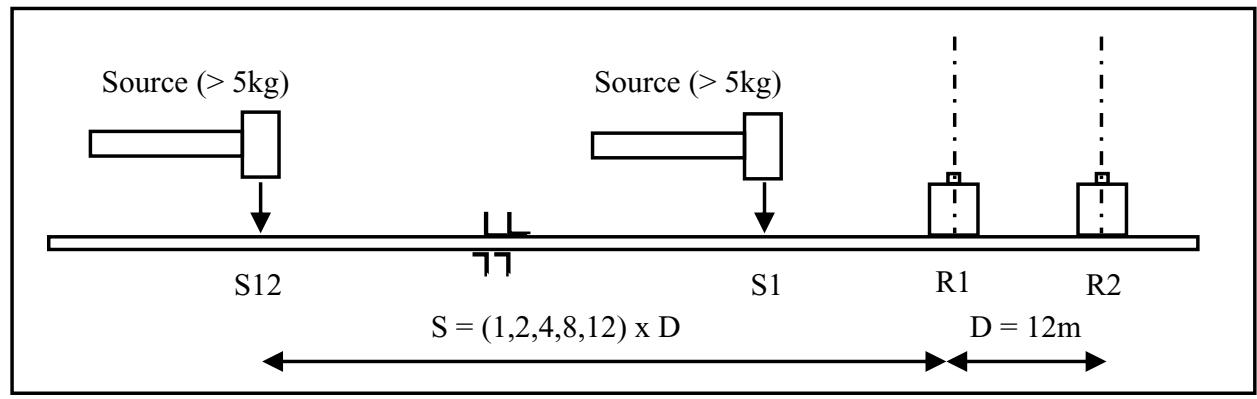

Fig. 2. Field configuration of SASW method based on Common Array Profiling (CAP).[11]

The location of SASW test were performed at the nearest point or borehole of Standard Penetration Test (SPT), as shown in Fig. 1. The raw SASW data was obtained using the National Instrument USB6289 data acquisition system with the WinSASW 3.2.12 and were analysed to produce $\mathrm{V}_{\mathrm{s}}$. All steps are analysed using the procedure developed by [12]. 


\section{Result and discussion}

Table 1 shows a summary of a detailed soil profile information for Site 1, Site 2 and Site 3. At Damansara and Kuala Lumpur test site have one borehole provided, while at Nilai test site have two boreholes. The information given indicates that the residual soils were consists of several types of soil layers. For Site 1, SASW test was performed at depth of 9 $\mathrm{m}$ from the ground surface. For Site 2 and 3, SASW testing were performed at the beginning of the ground surface.

Table 1. Summary of borehole report

\begin{tabular}{|c|c|c|c|c|c|c|c|}
\hline \multirow{2}{*}{\multicolumn{2}{|c|}{$\begin{array}{l}\text { Site } 1 \\
\mathrm{BH} 1\end{array}$}} & \multirow{2}{*}{\multicolumn{2}{|c|}{$\begin{array}{c}\text { Site } 2 \\
\mathrm{BH} 2\end{array}$}} & \multicolumn{4}{|c|}{ Site 3} \\
\hline & & & & & BH3 & & BH4 \\
\hline $\begin{array}{l}\text { Depth, } \\
\text { m }\end{array}$ & $\begin{array}{c}\text { Description } \\
\text { of soil }\end{array}$ & $\begin{array}{c}\text { Depth, } \\
\text { m }\end{array}$ & $\begin{array}{c}\text { Description } \\
\text { of soil }\end{array}$ & $\begin{array}{c}\text { Depth, } \\
\text { m }\end{array}$ & $\begin{array}{c}\text { Description } \\
\text { of soil }\end{array}$ & $\begin{array}{c}\text { Depth, } \\
\text { m }\end{array}$ & $\begin{array}{c}\text { Description } \\
\text { of soil }\end{array}$ \\
\hline 1.5 & Sandy silt & 3 & $\begin{array}{c}\text { Silty sand } \\
\text { with some } \\
\text { gravel }\end{array}$ & 1 & Sandy silt & 2.1 & Silty clay \\
\hline 4.5 & Sandy silt & 7 & $\begin{array}{c}\text { Sandy silt } \\
\text { with little } \\
\text { gravel }\end{array}$ & 3 & Sandy clay & 7.8 & Sandy silt \\
\hline 9.0 & Silty sand & 9 & Sandy silt & 10 & Sandy silt & 15.1 & Sandy silt \\
\hline 13.5 & $\begin{array}{c}\text { Silty sand } \\
\text { with little } \\
\text { gravel }\end{array}$ & 11 & Sandy silt & 13 & $\begin{array}{l}\text { Weathered } \\
\text { sandstone }\end{array}$ & - & \\
\hline 15.0 & Sandy clay & 14 & Sandy silt & - & & - & \\
\hline 18.0 & Sandy silt & 21 & Sandy silt & - & & - & \\
\hline 20.3 & $\begin{array}{c}\text { Sandy silt } \\
\text { with little } \\
\text { gravel }\end{array}$ & 25 & Clay & - & & - & \\
\hline 24.8 & Granite & - & & - & & - & \\
\hline
\end{tabular}

Based on the analysis of dispersion curve, the estimated depth of soil for $\mathrm{V}_{\mathrm{s}}$ profiles are respectively at $22 \mathrm{~m}, 34 \mathrm{~m}, 20 \mathrm{~m}, 16$ and $15 \mathrm{~m}$, which is correspond to the depth obtained from the borehole results. The relationship between SPT-N values and $\mathrm{V}_{\mathrm{s}}$ profiles have shown in Fig. 3 and Fig. 4. It clearly shows that the $V_{s}$ values are directly proportional to the increasing with depth of soil. The $V_{s}$ values above $500 \mathrm{~m} / \mathrm{s}$ was considered to achieve the stability for types of soil, respectively. This is proved where the $\mathrm{V}_{\mathrm{s}}$ profiles for Fig. 3a, Fig. $3 \mathrm{~b}$ and Fig. $4 \mathrm{a}$, shows the $\mathrm{V}_{\mathrm{s}}$ above $500 \mathrm{~m} / \mathrm{s}$ is corresponding to the SPT-N, more than 40 blows at the same depth. However, at same depth of $V_{s}$ profiles in Fig. $4 b$ and Fig. $4 c$, the $\mathrm{V}_{\mathrm{s}}$ values reached $500 \mathrm{~m} / \mathrm{s}$ on the number of SPT-N, only with 20 blows. In general, this condition is due to the concept of handling SASW tests, which involves the spread of geometry of Rayleigh waves in vertical soil strata, while the SPT test conducted is focussed on one point based on the selected borehole. 
(a)

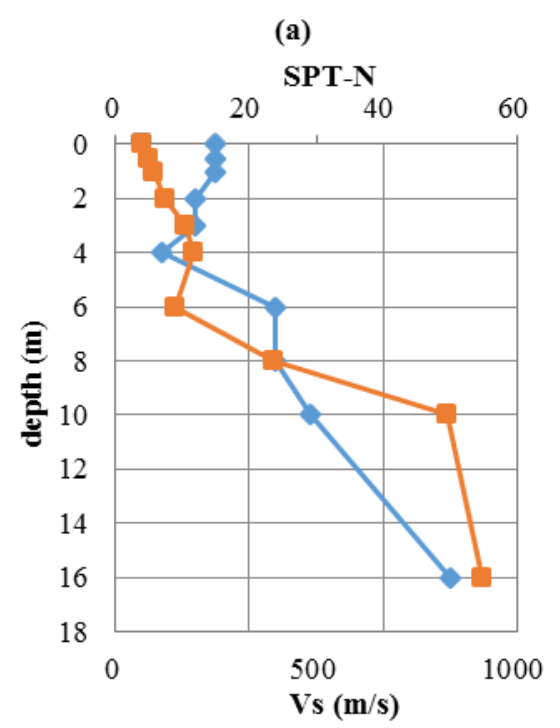

Note:

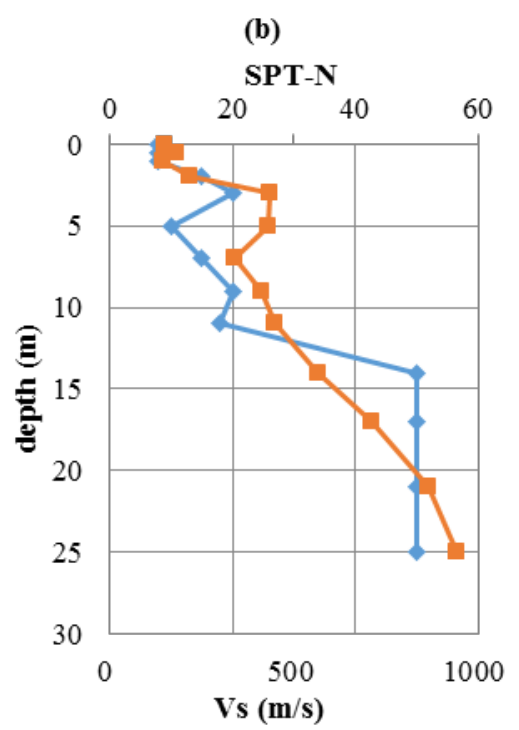

Fig. 3. $V_{\text {s }}$ profile and SPT-N with depth for a) Site 1 and b) Site 2.

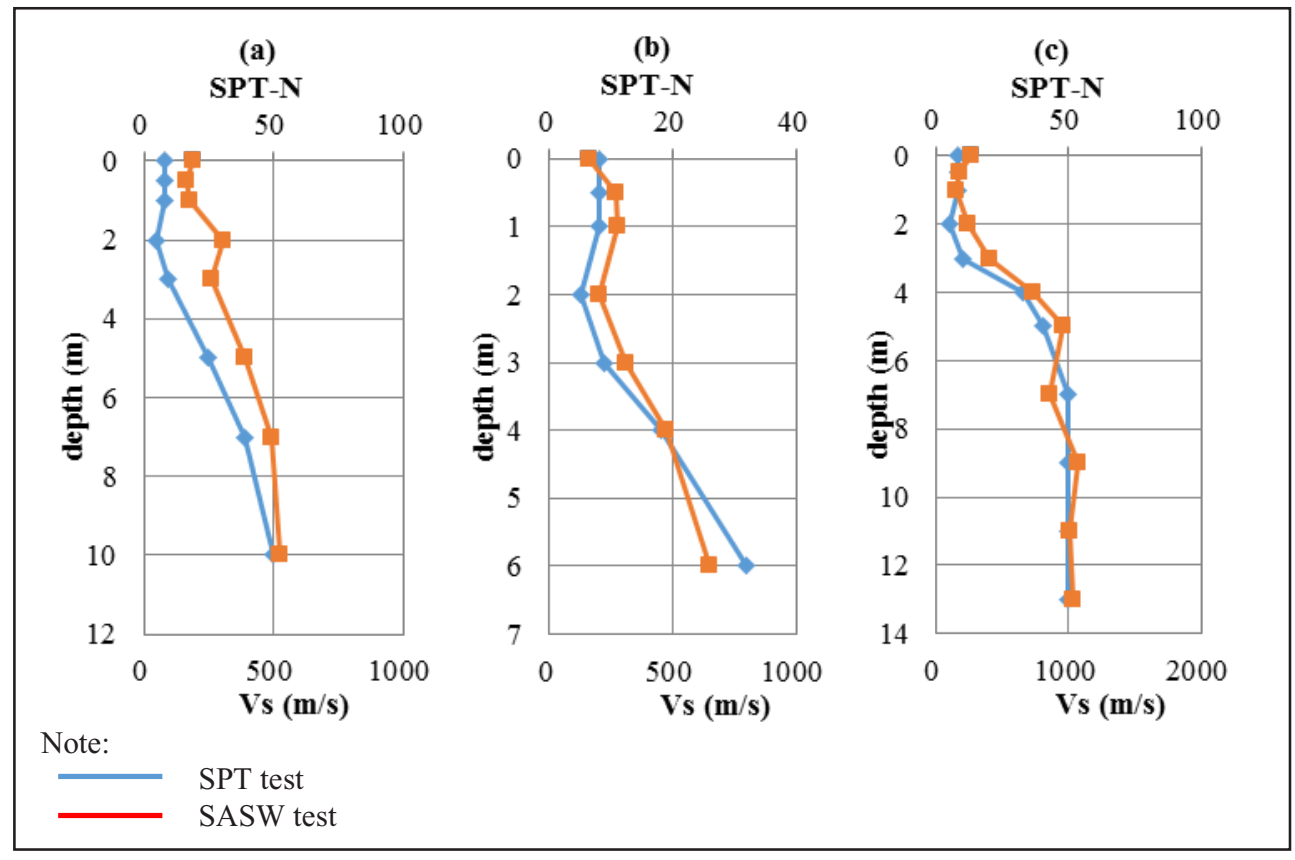

Fig. 4. $V_{s}$ profile and SPT-N with depth for three location test at Site 3. 


\section{Conclusion}

As a conclusion, it can be summarized that shear wave velocity profiles obtained from SASW method are reliable to the SPT-N values. The profiles were correlated well with borehole data and SPT-N values. Thus, SASW method can be useful in estimating the engineering properties of soil. In addition, this method has the advantage of being fast, practical and non-destructive tool for engineers in measuring engineering soil properties compared to the conventional method.

The author would like to acknowledge Ministry of Higher Education (MOHE), Malaysia for the sponsor and financial support under grant number of FRGS/1/2015/TK01/UNIMAP/02/1.

\section{References}

1. S. Foti, C.G. Lai, G.J. Rix, C. Strobbia, CRC Press (2014)

2. S. Nazarian, K.H. Stokoe, W.R. Hudson, Centre for Transportation Research (1983)

3. C.B. Park, R.D. Miller, J. Xia, Geophysics, 64, 800-808 (1999)

4. S. Nazarian, In situ determination of elastic moduli of pavement systems by spectral analysis of surface waves method (practical aspects) (1984)

5. K. Tokeshi, P. Harutoonian, C.J. Leo, S. Liyanapathirama, Advanc. in Geosciences, 35, 37-44 (2013)

6. K.H. Stokoe, G.W. Wright, A.B. James, M.R. Jose, Geophysical Characterization of Sites (1994)

7. J. Xia, R.D. Miller, C.B. Park, Geophysics, 64, 691-700 (1999)

8. P. Anbazaghan, A. Parihar, H.N. Rashimi, Soil Dynamic and Earthquake Engineering, 36, 52-69 (2012)

9. Fauzi, M. Irsyam, U.J. Fauzi, International Journal of Geomate, 7, 980-984 (2014)

10. G.J. Rix, G.G. Oroczo, M.C. Hebeler, V. Roma, Proceeding of the Fifteenth International Conf. on Soil Mechanics, 3, 499-502 (2001)

11. S.H. Joh, T.H. Kang, D.W. Jang, I.W. Lee, Journal of the Korean Geotechnical Society, 21, 71-81 (2005)

12. S.H. Joh, Advances in the data interpretation technique for spectral analysis of surface waves (SASW) measurements (1996) 